\title{
Penerapan Model Pembelajaran Penemuan Terbimbing (Guided Discovery Learning) untuk Meningkatkan Hasil Belajar dan Keterampilan Proses Sains Siswa
}

\author{
Hanis Destrini, Nirwana, Indra Sakti \\ Program Studi Pendidikan Fisika, JPMIPA FKIP Universitas Bengkulu \\ Jalan Raya Kandang Limun No 1 Bengkulu 38123 \\ E-mail : destrinih@gmail.com
}

\begin{abstract}
ABSTRAK
Penelitian ini merupakan penelitian tindakan kelas yang bertujuan untuk mendeskripsikan peningkatan hasil belajar, keterampilan proses sains dan aktivitas belajar siswa dilaksanakan dalam tiga siklus. Subjek dalam penelitian ini adalah seluruh siswa kelas X MIPA A SMA Negeri 2 Kota Bengkulu yang berjumlah 32 orang. Hasil penelitian ini menunjukkan bahwa hasil belajar siswa dalam aspek pengetahuan atau tes soal pada siklus I diperoleh daya serap siswa $63 \%$ dan ketuntasan belajar $16 \%$ (belum tuntas), meningkat pada siklus II diperoleh daya serap siswa $74 \%$ dan ketuntasan belajar $56 \%$ (belum tuntas), dan meningkat lagi pada siklus III diperoleh daya serap siswa $80 \%$ dan ketuntasan belajar $87 \%$ (tuntas). Skor rata-rata keterampilan proses sains siswa pada siklus I sebesar 70, pada siklus II sebesar 83, dan pada siklus III sebesar 88, dan aktivitas belajar siswa pada siklus I dengan rata-rata skor sebesar 20 dalam kategori cukup, siklus II sebesar 24,3 dalam kategori baik, dan pada siklus III sebesar 27,9 dalam kategori baik. Untuk penelitian selanjutnya sebaiknya menggunakan teknik pengumpulan data yang lebih lengkap untuk meneliti keterampilan proses sains agar dapat melihat hasil yang maksimal.
\end{abstract}

Kata kunci : Model Pembelajaran Penemuan Terbimbing, Hasil Belajar Fisika, Keterampilan Proses Sains Siswa.

\begin{abstract}
This research was a classroom action research aimed to describe student learning outcomes, science process skill student's and the learning activites conducted in three cycle. Subjects in this study were all students of class X MIPA A which amounted to 32 people. The results of this study indicated Students' learning outcomes in the knowledge or test aspects of the first cycle obtained by students absorption $63 \%$ and mastery learn $16 \%$ (not yet completed), increased in cycle II obtained by students absorbance $74 \%$ and mastery learn $56 \%$ (not yet completed), and increased in cycle III obtained by students absorption $80 \%$ and mastery learn $87 \%$ (completed). Science process skill student's score in cycle $\mathrm{I}$ is 70 , in the second cycle of 83 , the third cycle of 88 . Student learning activity in cycle I with average score of 20 in category enough, cycle II of 24,3 in good category, and cycle III equal to 27,9 in good category. For further research should use more complete data collection techniques to examine the science process skills in order to see the maximum results.
\end{abstract}

Keywords: guided discovery, learning outcomes, science process skills

\section{PENDAHULUAN}

Pendidikan adalah usaha sadar yang dilakukan oleh individu atau kelompok tertentu melalui kegiatan pengajaran atau pelatihan, yang berlangsung sepanjang hidup di berbagai lingkungan belajar dalam rangka mempersiapkan manusia agar dapat memainkan peran dengan tepat [1]. Sebagian besar negara mengutamakan pendidikan untuk menciptakan sumber daya manusia yang mampu meningkatkan kemajuan di negara itu sendiri. Fisika merupakan salah satu bagian dari mata pelajaran sains yang nyatanya memiliki peran yang besar dalam mendukung kemajuan ilmu pengetahuan dan teknologi. Pada saat kita mengajar mata pelajaran sains khususnya pelajaran fisika, hendaknya seorang guru berpikir bagaimana 
mata pelajaran fisika ini dapat membentuk siswa yang pada akhinya akan memiliki sikap, kecerdasan, dan keterampilan secara bersamaan.

Sekolah Menengah Atas (SMA) Negeri 2 Kota Bengkulu telah menerapkan Kurikulum 2013 sejak tahun ajaran 2013/2014 hingga saat ini. Berdasarkan hasil wawancara yang telah dilakukan dengan guru mata pelajaran fisika di kelas X MIPA A SMA Negeri 2 Kota Bengkulu didapat beberapa fakta yang ada antara lain, metode pembelajaran yang sering digunakan dalam proses pembelajaran antara lain metode ceramah, tutor sebaya, eksperimen dan latihan soal. Nilai akhir rata-rata pelajaran fisika di kelas X MIPA A merupakan nilai rata-rata terendah dibanding 5 kelas lainnya. Siswa-siswi kelas X MIPA A kurang aktif dalam merespon guru di pembelajaran fisika, masih terdapat beberapa siswa yang acuh pada saat proses pembelajaran berlangsung. Selain itu pada aspek keterampilan proses sains siswa di Kelas X MIPA A juga masih kurang pada beberapa aspek seperti pada aspek keterampilan membuat hipotesis, merencanakan percobaan, menggunakan alat dan bahan, mengamati dan menafsirkan.

Solusi dari beberapa masalah yang ada di kelas X MIPA A SMA Negeri 2 Kota Bengkulu, diperlukan upaya perbaikan dalam proses pembelajaran agar hasil belajar, keterampilan proses dan aktivitas siswa pada pelajaran fisika dapat meningkat. Upaya peningkatan akan dilakukan dengan menerapkan model pembelajaran yang tepat, salah satunya yaitu model pembelajaran penemuan (discovery learning). Model pembelajaran penemuan terbagi menjadi dua jenis yaitu penemuan bebas (free discovery) dan penemuan terbimbing (guided discovery). Pada penelitian ini akan digunakan model penemuan terbimbing (guided discovery learning).

Dipilihnya model pembelajaran penemuan terbimbing (guided discovery learning) sebagai alternatif model pembelajaran yang akan digunakan di kelas X MIPA A SMA Negeri 2 Kota Bengkulu dikarena beberapa kelebihan dari model tersebut. Model pembelajaran guided discovery dapat memberikan kesempatan kepada peserta didik untuk terlibat aktif dalam menemukan konsep dan pengetahuan, memberikan kesempatan kepada peserta didik untuk mengembangkan keterampilan proses sains melalui kegiatan praktik dan memberikan kesempatan kepada peserta didik untuk melatih kemampuan berpikir [2].

Pemilihan model penemuan terbimbing sebagai alternatif model pembelajaran yang akan digunakan di kelas X MIPA A SMA Negeri 2 Kota Bengkulu juga karena model pembelajaran penemuan terbimbing merupakn model pembelajaran yang sesuai untuk melatihkan keterampilan proses sains adalah model pembelajaran guided discovery [3]. Model pembelajaran penemuan terbimbing ini juga dapat meningkatkan keterampilan proses sains siswa kelas X SMK Negeri 2 Bangkalan [4].

Berdasarkan uraian masalah diatas, maka dianggap perlu untuk diadakan penelitian tindakan kelas (PTK) di SMA Negeri 2 Kota Bengkulu, dengan judul penelitian "Penerapan Model Pembelajaran Penemuan Terbimbing (Guided Discovery Learning) Untuk Meningkatkan Keterampilan Proses, dan Hasil Belajar Siswa Pada Materi Getaran Harmonik di Kelas X MIPA A SMA Negeri 2 Kota Bengkulu."

Adapun rumusan masalah pada penelitian ini adalah : (1) Apakah dengan menerapkan model pembelajaran penemuan terbimbing (guided discovery learning) dapat meningkatkan hasil belajar siswa kelas X MIPA A SMA Negeri 2 Kota Bengkulu pada materi getaran harmonik, (2) Apakah dengan menerapkan model pembelajaran penemuan terbimbing (guided discovery learning) dapat meningkatkan keterampilan proses siswa kelas X MIPA A SMA Negeri 2 Kota Bengkulu pada materi getaran harmonik, (3) Apakah dengan menerapkan model pembelajaran penemuan terbimbing (guided discovery learning) dapat meningkatkan aktivitas belajar siswa kelas X MIPA A SMA Negeri 2 Kota Bengkulu pada materi getaran harmonik. 


\section{METODE PENELITIAN}

Jenis penelitian yang digunakan adalah Penelitian Tindakan Kelas (Classroom Action Research). Subjek dalam penelitian ini adalah siswa kelas X MIPA A SMA Negeri 2 Kota Bengkulu Semester II Tahun 2017/2018 yang jumlahnya 32 orang siswa. Penelitian ini dilaksanakan pada bulan Maret 2018 - April 2018.

Prosedur penelitian tindakan kelas yang akan dilaksanakan berupa proses pengkajian bertahap yang terdiri dari 4 tahap yaitu: 1) perencanaan tindakan, 2) pelaksanaan tindakan, 3) observasi dan 4) analisa dan refleksi [5]. Pelaksanaan pembelajaran terdiri atas 3 siklus. Teknik pengumpulan data yang digunakan adalah tes hasil belajar, lembar observasi keterampilan proses sains, dan lembar observasi aktivitas guru dan siswa. Data yang diperoleh adalah hasil belajar fisika ranah kognitif, keterampilan proses sains siswa dan aktivitas belajar siswa dan aktivitas guru. Data tes hasil selama 3 siklus dikumpulkan kemudian dianalisi dengan menghitung :

\subsection{Analisis Hasil Belajar Siswa}

\subsubsection{Nilai rata-rata siswa [6]}

$$
\bar{X}=\sum_{i=1}^{n} \frac{X_{i}}{n}
$$

Keterangan:

$$
\begin{array}{ll}
\bar{X} & \text { : Nilai rata-rata } \\
\sum_{i=1}^{n} X_{i} & \text { : Jumlah nilai } \\
n & \text { : Jumlah siswa }
\end{array}
$$

\subsubsection{Daya serap klasikal}

$$
D S=\frac{N S}{S \times N I} \times 100 \%
$$

Keterangan :

DS : Daya serap siswa

NS : Jumlah nilai seluruh siswa

$S \quad$ : Jumlah siswa

NI : Nilai ideal

\subsubsection{Ketuntasan belajar secara klasikal}

$$
K B=\frac{N^{\prime}}{N} x 100 \%
$$

Keterangan:

KB : ketuntasan belajar secara klasikal

N' : jumlah siswa yang skornya $\geq 75$

$\mathrm{N} \quad$ : jumlah siswa keseluruhan

\subsection{Analisis Keterampilan Proses Sains}

Analisis data lembar kerja siswa pada penilaian ini menggunakan 5 aspek penilaian, yaitu 1) membuat hipotesis, 2) merencanakan percobaan, 3) mengunakan alat dan bahan, 4) mengamati, dan 5) menafsirkan/menyimpulkan. Adapun untuk mendapatkan skor akhir digunakan rumus sebagai berikut:

$$
\text { Skor }=\frac{\text { Skor Perolehan }}{\text { Skor maksimal }} \times 100
$$

Penilaian aspek keterampilan akan ditulis menggunakan skala penilaian dengan interval seperti Tabel 1. berikut :

Tabel 1. Konversi Penilaian Keterampilan [7] 


\begin{tabular}{|c|c|}
\hline Skor & Kategori \\
\hline $81-100$ & Sangat Baik (A) \\
\hline $61-80$ & Baik (B) \\
\hline $41-60$ & Cukup (C) \\
\hline $21-40$ & Kurang (D) \\
\hline $0-20$ & Sangat Kurang (D) \\
\hline
\end{tabular}

\subsection{Analisis Aktivitas Guru dan Siswa}

Kisaran nilai rata-rata yang diperoleh pada setiap langkah dapat dicari dengan persamaan :

$$
\begin{aligned}
\text { Kisaranskorrata }- \text { ratatiapaspek } & =\frac{\text { skortertinggi }- \text { skorterendah }}{\text { skortertinggitiapaspek }} \\
& =\frac{3-1}{3}=0,66
\end{aligned}
$$

Kisaran penilaian untuk skor rata-rata aktivitas belajar guru dan siswa dapat dilihat pada Tabel 2.

Tabel 2. Kriteria Penilaian Skor Rata-rata Tiap Aspek Aktivitas Belajar Guru dan Siswa

\begin{tabular}{|c|c|}
\hline Kriteria & Skor Rata-rata \\
\hline Kurang & $1,00-1,66$ \\
\hline Cukup & $1,67-2,33$ \\
\hline Baik & $2,34-3,00$ \\
\hline
\end{tabular}

Skor akhir untuk hasil observasi aktivitas guru dan siswa diperoleh dari jumlah keseluruhan skor rata-rata tiap tahapan. Sedangkan untuk mencari interval skor akhir dari 10 butir observasi aktivitas guru dan siswa adalah sebagai berikut :

Skor tertinggi $=$ jumlah butir observasi $\mathrm{x}$ skor tertinggi tiap butir

$$
=10 \times 3=30
$$

Skor terendah $=$ jumlah butir observasi $\mathrm{x}$ skor terendah tiap butir

$$
=10 \times 1=10
$$

Selisish skor $=$ skor tertinggi - skor terendah

$$
=30-10
$$$$
=20
$$

Interval kriteria $=\frac{\text { selisih } \text { skor }}{\text { jumlah } \text { kriteria penilaian }}=\frac{20}{3}=6,666=7$

Tabel 3. Interval Kategori Penilaian Observasi Aktivitas Siswa [8]

\begin{tabular}{|c|c|c|}
\hline No & Interval & Interpretasi Penilaian \\
\hline 1 & $10-16$ & Kurang \\
\hline 2 & $17-23$ & Cukup \\
\hline 3 & $24-30$ & Baik \\
\hline
\end{tabular}

\section{HASIL DAN PEMBAHASAN}

\subsection{Hasil Belajar Siswa Aspek Pengetahuan Tiga Siklus} Gambar 1.

Data hasil belajar aspek pengetahuan siswa dari siklus ke siklus dapat dilihat pada 


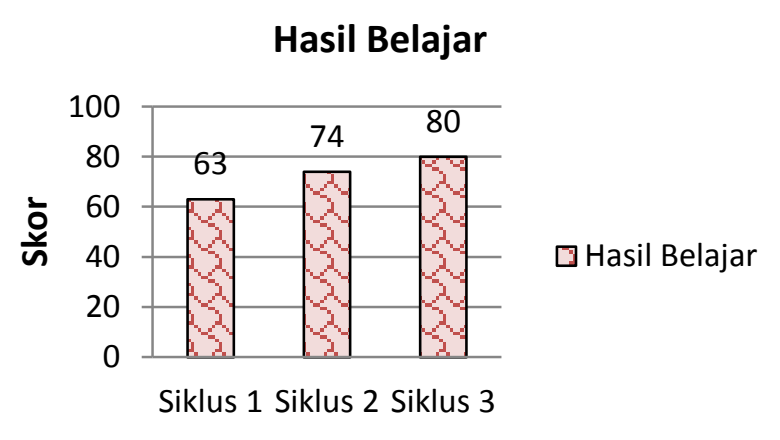

Gambar 1. Grafik Nilai Pengetahuan Setiap Siklus

Skor rata-rata hasil belajar pada siklus I adalah 63 artinya nilai rata-rata hasil belajar siswa belum diatas nilai KKM, hal ini terjadi karena selama proses pembelajaran berlangsung, masih terdapat siswa yang kurang serius dalam pembelajaran, siswa masih banyak yang terlihat bingung dengan prosedur yang ada di LKS dan masih ada yang main-main saat praktikum berlangsung, sehingga siswa mengalami kesulitan dalam menguasai materi yang dipelajari. Selain itu, pada saat guru memberikan penguatan setelah praktikum berlangsung, siswa tidak mencatat apa yang guru jelaskan kembali. Sehingga tidak bisa mengerjakan soal tes dengan benar pada akhir pembelajaran.

Selama pembelajaran pada siklus I, didapat bahwa masih terdapat siswa yang mendapatkan skor tes akhir belajar yang belum tuntas, hanya 5 orang siswa yang dikatakan tuntas dari 32 orang siswa di kelas X MIPA A. Skor terendah pada siklus ini adalah 46. Hasil belajar siswa pada aspek pengetahuan belum dapat dikatakan tuntas secara klasikal.

Skor rata-rata hasil belajar pada siklus II mengalami peningkatan dari siklus sebelumnya yaitu sebesar 74, namun nilai rata-rata hasil belajar siswa pada siklus II ini masih belum diatas nilai KKM. Hal ini terjadi karena masih ada beberapa siswa yang belum memperhatikan betul pada saat guru menerangkan materi dan juga siswa main-main pada saat praktikum berlangsung, kemudian juga masih ada beberapa siswa yang tidak mencatat apa yang telah dijelaskan guru. Sehingga masih kesulitan dalam mengerjakan soal tes pada akhir pembelajaran dengan tepat.

Selama siklus II ini terjadi peningkatan jumlah siswa yang tuntas pada saat tes akhir berlangsung, terdapat 18 siswa yang tuntas, namun masih ada siswa 14 orang siswa yang tidak tuntas. Skor terendah pada siklus ini adalah 58. Sama halnya dengan siklus I, pada siklus II ini pun secara klasikal hasil belajar siswa untuk aspek pengetahuan belum dapat dikatakan tuntas.

Skor rata-rata hasil belajar pada siklus III mengalami kenaikan menjadi 80 dapat dikatakan siswa secara rata-rata sudah menguasai materi yang telah diajarkan oleh guru dan nilai akhir rata-rata siswa kelas X MIPA A sudah diatas KKM, namun masih ada 4 orang siswa yang tidak tuntas saat melakukan tes pada akhir pembelajaran siklus ini. Pada siklus III ini pun secara klasikal hasil belajar siswa apek pengetahuan telah dikatakan tuntas.

Ketuntasan belajar siswa secara klasikal siswa pada siklus I belum dikatakan tuntas karena jumlah siswa yang tuntas tidak mencapai $85 \%$ tetapi hanya $16 \%$. Kekurangan ini dapat diperbaiki pada siklus berikutnya sehingga untuk siklus berikutnya tingkat ketuntasan belajar siswa secara klasikal lebih baik yaitu sebesar 56\% akan tetapi masih belum dikatakan tuntas secara klasikal, namun pada siklus III ketuntasan secara klasikal siswa dikatakan tuntas secara klasikal sebesar $87 \%$ yang mana telah mencapai indikator keberhasilan sebesar $85 \%$. Peningkatan ini menunjukkan bahwa ada perubahan atau perbaikan proses pembelajaran sehingga penguasaan materi oleh siswa juga semakin meningkat menjadi lebih baik setiap siklusnya.

Hal ini sesuai dengan hasil penelitian Husen Jauwad (2015) yang menyatakan bahwa pembelajaran dengan model pembelajaran guided discovery learning dapat meningkatkan 
hasil belajar siswa [9], dan Nur Aini Atush (2015) dalam penelitiannya yang menyatakan bahwa model pembelajaran guided discovery learning dapat meningkatkan hasil belajar siswa.[10]

\subsection{Keterampilan Proses Sains Siswa Tiga Siklus}

Peningkatan rata-rata skor akhir kelas X MIPA A SMA Negeri 2 Kota Bengkulu untuk aspek keterampilan proses sains pada tiap siklus digambarkan oleh grafik pada Gambar 2.

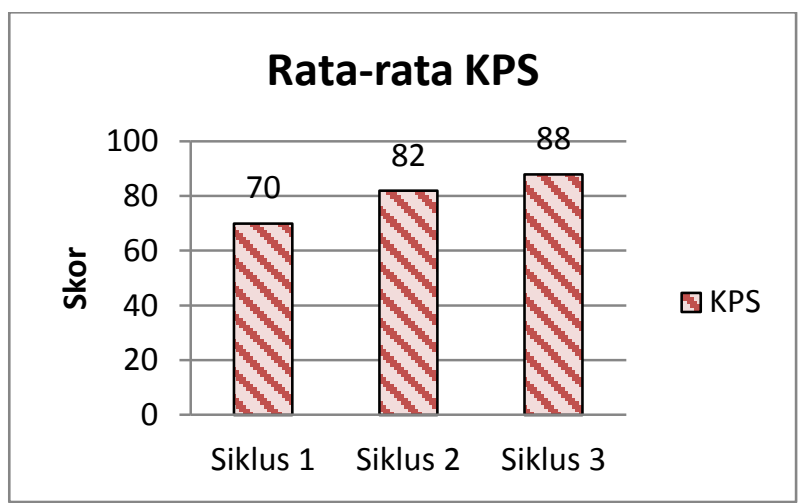

Gambar 2. Grafik Data Skor Rata-Rata KPS Per Siklus

Rata-rata skor akhir siswa X MIPA A SMA Negeri 2 Kota Bengkulu pada keterampilan proses sains siswa dari siklus I hingga siklus III mengalami peningkatan. Pada siklus I dengan materi Karakteristik Getaran Harmonik Pada Pegas didapat bahwa skor ratarata akhir dari 5 aspek keterampilan proses sains siswa pada siklus I ini sebesar 70 dengan kategori baik, pada siklus II dengan materi Karakteristik Getaran Harmonik Pada Bandul didapat bahwa skor rata-rata akhir dari 5 aspek keterampilan proses sains siswa pada siklus II ini mengalami kenaikan menjadi 82 dengan kategori sangat baik, dan pada siklus III dengan materi Persamaan Simpangan didapat bahwa skor rata-rata akhir dari 5 aspek keterampilan proses sains mengalami kenaikan menjadi 88 dengan kategori sangat baik.

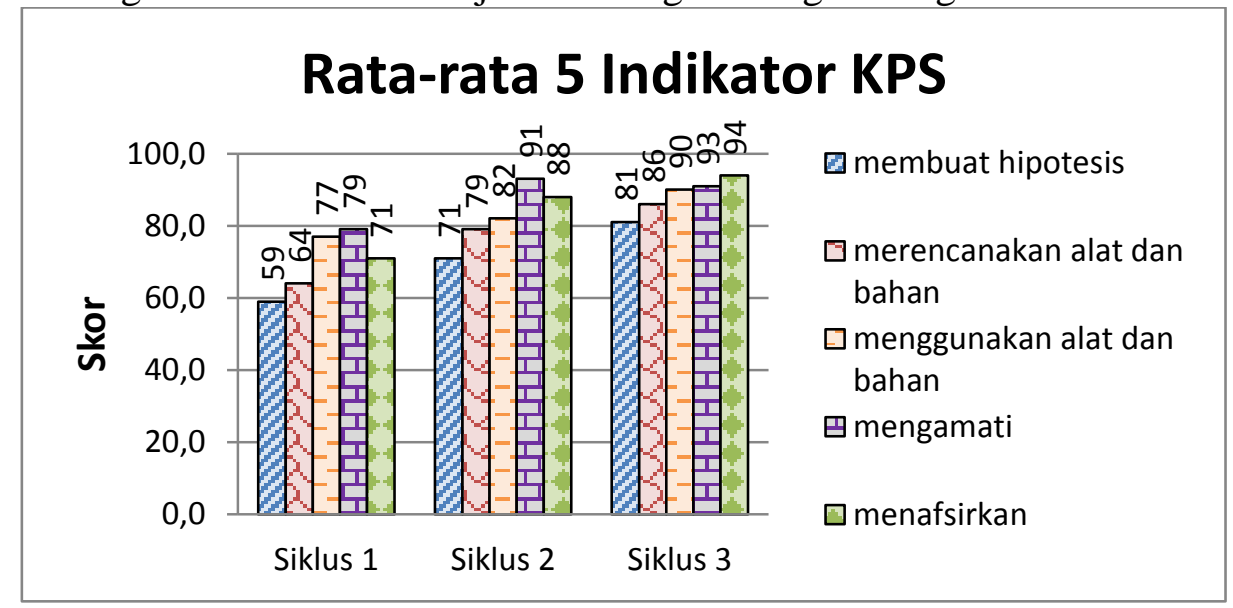

Gambar 3. Grafik dan Skor Rata-rata per Indikator KPS

Skor rata-rata indikator membuat hipotesis pada siklus I adalah 59 dalam kategori cukup, pada siklus I ini siswa masih banyak yang terlihat bingung dalam membuat hipotesis pada saat melakukan praktikum, siswa masih bingung membedakan antara variabel bebas dan variabel terikat, kemudian pada siklus II skor rata-rata untuk indikator membuat hipotesis mengalamai kenaikan sebesar 71 dalam kategori baik, pada siklus II ini beberapa siswa sudah dapat membedakan antara variabel bebas dan terikat, kemudian pada siklus III skor rata-rata naik kembali menjadi 81 dalam kategori sangat baik, pada siklus III ini siswa sudah mulai terbiasa dan sudah paham dalam menentukan variabel bebas dan terikat.

Indikator kedua KPS yaitu merencanakan percobaan skor rata-rata untuk indikator ini pada siklus I sebesar 64 dalam kategori baik, hal ini dikarenakan masih terdapat beberapa 
siswa yang masih belum terbiasa dalam menentukan urutan langkah percobaan sendiri, dan juga siswa masih kesulitan dalam menentukan nama-nama alat dan bahan untuk praktikum.

Skor rata-rata siklus II pada indikator ini mengalami kenaikan menjadi 79 dalam kategori baik, hal ini dikarenakan siswa sudah mulai memahami dan mulai terbiasa untuk menyusun kembali dari langkah-langkah percobaan dan juga hal ini disebabkan alat dan bahan yang digunakan pada pembelajaran siklus II ini hampir sama dengan alat dan bahan yang digunakan pad praktikum di siklus I.

Skor rata-rata indikator merencanakan percobaan pada siklus III juga mengalami kenaikan yang cukup besar menjadi 86 dengan kategori sangat baik. Hal ini terjadi karena siswa semakin terbiasa pada saat melakukan kegiatan praktikum, dan mengurutkan langkah percobaannya. Dari data tersebut, perubahan skor rata-rata indikator KPS merencanakan percobaan mengalami kenaikan dari siklus I, II dan III.

Indikator ketiga KPS pada penelitian ini adalah menggunakan alat dan bahan. Skor ratarata pada siklus I 77 dalam kategori baik, pada siklus II 82 dalam kategori sangat baik, dan pada siklus III sebesar 90 dalam kategori sangat baik. Pada indikator KPS ini skor rata-rata mengalami kenaikan yang cukup besar pada siklus II dan III, namun pada siklus I dan II mengalami kenaikan yang tidak terlalu besar.

Indikator KPS yang keempat pada penelitian ini adalah mengamati, siswa diminta untuk mengamati percobaan yang dilakukan. Skor rata- rata pada siklus I sebesar 79 dalam kategori baik, siklus II sebesar 91 dalam kategori sangat baik, dan pada siklus III sebesar 93 dalam kategori sangat baik. Pada indikator ini setiap siklusnya mengalami kenaikan skor rata-rata pada siklus I - III. Hal ini terjadi karena, siswa merasa tertarik pada saat melakukan kegiatan praktikum, sehingga siswa-siswa sangat antusias pada saat kegiatan mengamati.

Indikator yang terakhir pada penelitian ini adalah menyimpulkan. Menyimpulkan pada penelitian ini berupa deskripsi dari hasil percobaan yang dilakukan sesuai dengan materi. Skor rata-rata siklus I sebesar 71 dalam kategori baik, pada siklus 1 ini masih terdapat beberapa siswa yang masih bingung pada saat menghubungkan data hasil percobaan dengan materi pembelajaran, namun pada siklus II skor rata-rata mengalami kenaikan yang cukup signifikan sebesar 88 dalam kategori sangat baik dan pada siklus III sebesar 94 dalam kategori sangat baik, hal ini terjadi karena pada siklus II dan III siswa sudah mulai terbiasa dan mengerti untuk menghubungkan data hasil percobaan dengan mater yang diajarkan. Dari data tersebut dapat diketahui bahwa pada indikator KPS menafsirkan mengalami kenaikan tiap siklusnya hingga pada siklus terakhir mendapat skor dengan kategori baik.

Hal ini selaras dengan hasil penelitian Eko Teguh Wibowo (2016) yang menyatakan bahwa model guided discovery dapat meningkatkan keterampilan proses sains dan hasil belajar [11], dan penelitian Fitri \& Dwikoranto (2016) yang menyatakan bahwa penerapan model guided discovery dapat meningkatkan keterampilan proses sains siswa.[12]

\subsection{Aktivitas Belajar Siswa Tiga Siklus \\ Peningkatan aktivitas siswa seperti pada Gambar 4.}




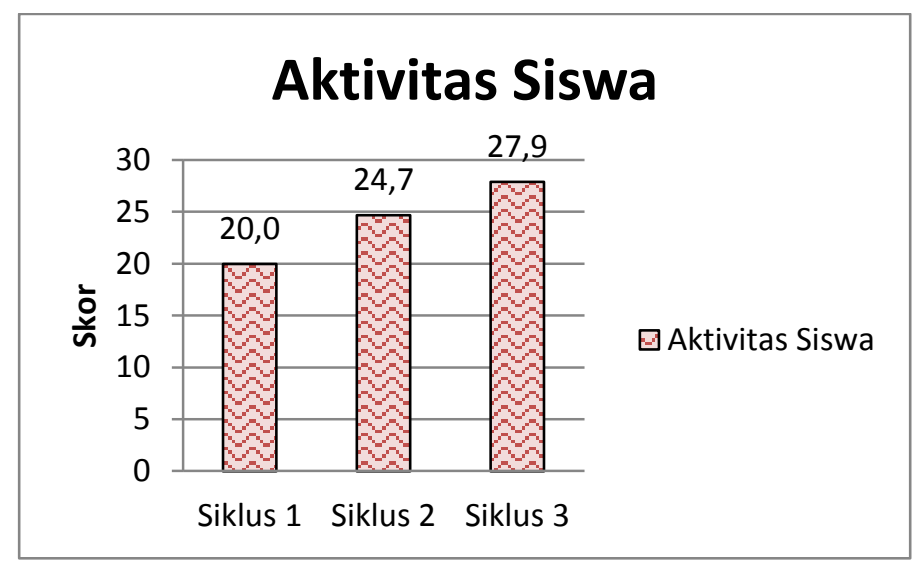

Gambar 4. Grafik Perkembangan Skor Aktivitas Siswa

Aktivitas siswa pada siklus I memperoleh skor rata-rata keseluruhan yaitu 20,0, aktivitas siswa kemudian meningkat pada siklus II menjadi 24,7, dan mengalami peningkatan kembali pada siklus III menjadi 27,9. Pada fase merumuskan masalah, siswa masih kurang bisa merumuskan masalah dan kurang berani untuk bertanya karena kurang memperhatikan pengamatan dan penjelasan guru pada saat demonstrasi. Hal ini terjadi karena siswa belum terbiasa dalam membuat rumusan masalah terhadap masalah yang diberikan.

Pada fase mengumpulkan data, menyusun, memproses, mengornasisir dan menganalisis data guru memberikan kesempatan siswa dalam mengumpulkan data dari percobaan yang dilakukan. Siswa masih mengalami kesulitan dalam mengolah dan menganalisa data yang didapat dari hasil percobaan sehingga siswa diajak lebih berpartisipasi lagi dalam menganalisa data yang telah diperoleh dari percobaan.

Pada fase menyusun prakiraan, siswa melakukan pembuktian hasil pengamatan terhadap sumber materi yang ada. Berdasarkan hasil pengamatan siswa belum optimal melakukan pembuktian hasil percobaan terhadap sumber materi yang ada sehingga disetiap siklusnya siswa harus berupaya untuk meningkatkan dan memperbaiki kekurangan tersebut dengan siswa diberi arahan dan bimbingan guru agar melakukan pembuktian terhadap hasil yang didapat dengan teori yang ada.

Pada fase verbalisasi prakiraan, masih ada beberapa siswa yang bingung dalam menarik kesimpulan dari percobaan yang sudah dilaksanakan, hal ini didasari dengan kurangnya komunikasi antar kelompok dalam mendiskusikan hasil percobaan yang telah didapat dari percobaan, dari segi cara mengkomunikasikan siswa kelas X MIPA A SMA Negeri 2 Kota Bengkulu sudah terbiasa untuk menyampaikan hasil diskusi dengan percaya diri sehingga di setiap siklusnya siswa tidak terlalu mengalami kesulitan dan telah berani menyampaikan kesimpulan secara lisan.

Pada fase evaluasi, masih ada beberapa siswa yang mengalami kesulitan pada saat mengerjakan evaluasi pada akhir pembelajaran, selain itu juga masih ada beberapa siswa yang tidak mengerjakan soal evaluasi pada akhir pembelajaran dengan jujur, dan malah menyontek. Hal ini didasari oleh kurangnya keaktifan dan konsentrasi siswa pada saat pembelajaran berlangsung dan juga pada saat guru melakukan penguatan setelah melakukan percobaan sehingga di setiap siklusnya siswa harus berupaya untuk lebih giat, dan serius selama proses pembelajaran berlangsung agar dapat mengerjakan soal evaluasi dengan baik dan benar.

Hal ini selaras dengan hasil penelitian Tarigan (2012) dalam penelitiannya yang menyatakan bahwa pembelajaran dengan pendekatan saintifik dapat meningkatkan aktivitas belajar siswa.[13]

\section{KESIMPULAN DAN SARAN}

\subsection{Kesimpulan}

Berdasarkan hasil penelitian dan pembahasan, maka diperoleh kesimpulan sebagai berikut : (1) Penerapan model guided discovery learning dapat meningkatkan hasil belajar 
siswa pada materi getaran harmonik di kelas X MIPA A SMAN 2 Kota Bengkulu, (2) Penerapan model guided discovery learning dengan pendekatan saintifik dapat meningkatkan keterampilan proses sains siswa pada materi getaran harmonik di kelas X MIPA A SMA Negeri 2 Kota Bengkulu, dan (3) Penerapan model guided discovery learning dengan pendekatan saintifik dapat meningkatkan aktivitas belajar siswa pada materi getaran harmonik di kelas X MIPA A SMA Negeri 2 Kota Bengkulu.

\subsection{Saran}

Berdasarkan penelitian yang telah dilakukan, disarankan perbaikan penelitian dimasa yang akan datang agar pembelajaran lebih optimal disarankan kepada guru untuk dapat mengatur waktu selama pelaksanaan pengajaran, dan juga diharapkan pada penelitianpenelitian berikutnya sebelum melaksanakan penelitian semua kelengkapan yang dibutuhkan dalam penelitian dipersiapkan dengan semaksimal mungkin agar penelitian dapat berjalan dengan maksimal.

\section{DAFTAR PUSTAKA}

[1]Purwanto, N. (2014). Pengantar Pendidikan. Yogyakarta: Graha Ilmu.

[2]Rachayuni. (2016). Meningkatkan Keterampilan Proses Sains dan Hasil Belajar IPA melalui Penerapan Model Guided Discovery di Kelas VII-1 SMPN 32 Semarang. Jurnal Scientia Indonesia, 66-73.

[3]Azizirrahim, E., Sutrio, \& Gunawan. (2015). Penerapan Pendekatan keterampilan Proses Sains dalam Model Pembelajaran Guided Discovery untuk Meningkatkan Hasil Belajar IPA Fisika pada Siswa Kelas VII A SMPN 8 Mataram Tahun Ajaran 2015/2016. Pendidikan Fisika dan Teknologi, 272-275.

[4]Setiawan, F. A., \& Dwikoranto. (2016). Penerapan Model Pembelajaran Guided Discovery Untuk Meningkatkan Keterampilan Proses Sains Pada Materi Suhu dan Kalor di Kelas X SMK Negeri 2 Bangkalan. Jurnal Inovasi Pendidikan Fisika, 4.

[5]Trianto. (2011). Panduan Lengkap Penelitian Tindakan Kelas. Jakarta: Prestasi Pustaka.

[6]Sani, R. A., \& Sudiran. (2017). Penelitian Tindakan Kelas. Tanggerang: Tira Smart.

[7]Nirmalasari, Santiani, \& Rohmadi, H. (2016). Penerapan Model Pembelajaran Learning Cycle Terhadap Keterampilan Proses Sains dan Hasil Belajar Siswa Pada Pokok Bahasan Getaran Harmonis . Edusains.

[8]Agustin, Y., Medriati, R., \& Putri, D. H. (2017). Penerapan Model Inkuiri Terbimbing untuk Meningkatkan Hasil Belajar dan Keterampilan Proses Sains Siswa Pada Konsep Tekanan Di Kelas VIII 1 SMPN 3 Kota Bengkulu.

[9]Jauwad, H., \& Supriyono. (2015). Penerapan Model Guided Discovery Pada Materi Kalor Kelas X Untuk Meningkatkan Hasil Belajar Siswa SMA Al-Muhadul Islami. Jurnal Inovasi Pendidikan Fisika, 5.

[10]Sholihah, N. A., \& Sunarti, T. (2015). Penerapan Model Pembelajaran Guided Discovery dengan Pendekatan Saintifik Untuk Meningkatkan Hasil Belajar Siswa Pada Pokok Bahasan Perpindahan Kalor di Kelas X SMA Negeri 1 Geger Madiun. Jurnal Inovasi Pendidikan Fisika, 146-149.

[11]Wibowo, Teguh Eko. (20160. Penerapan Model Pembelajaran Guided Discovery untuk Meningkatkan Keterampilan Proses Sains dan Hasil Belajar Siswa.

[12]Setiawan, F. A., \& Dwikoranto. (2016). Penerapan Model Pembelajaran Guided Discovery Untuk Meningkatkan Keterampilan Proses Sains Pada Materi Suhu dan Kalor di Kelas X SMK Negeri 2 Bangkalan. Jurnal Inovasi Pendidikan Fisika, 4.

[13]Tarigan, D. (2012). Meningkatkan Aktivitas Belajar Siswa dengan Menggunakan Model Make A Match Pada Mata Pelajaran Matematika di Kelas V SDN 050687 Sawit Seberang. Kreano, 58. 